\title{
Anatomy and development of the reproductive units of Mapania pycnostachya and Hypolytrum schraderianum (Mapanioideae, Cyperaceae)
}

\author{
Mariana Maciel Monteiro ${ }^{\mathrm{A}, \mathrm{B}}$, Vera Lúcia Scatena $^{\mathrm{A}}$ and Aline Oriani ${ }^{\mathrm{A}}$ \\ ADepartamento de Botânica, Instituto de Biociências, Universidade Estadual Paulista, \\ Caixa Postal 199, 13506900 Rio Claro, SP, Brazil. \\ ${ }^{B}$ Corresponding author. Email: marimonteiro199@gmail.com
}

\begin{abstract}
The typical mapaniid reproductive unit, which comprises several bracts, stamens and a gynoecium, may be interpreted as a single flower. Although developmental studies suggest that the mapaniid reproductive units are inflorescences, the units in species such as Hypolytrum schraderianum Nees are much reduced and strongly resemble a single flower. Therefore, an anatomical and developmental study of the reproductive units of Mapania pycnostachya (Benth.) T.Koyama and H. schraderianum was conducted to better understand their structure. In both species, two lateral bracts (prophyll-like units) are the first to emerge, followed by staminal and gynoecial primordia. The reproductive units of M. pycnostachya have two inner bracts (leaf-like structures) that initiate after the stamens. In H. schraderianum, they are absent. In both species, the reproductive units have spiral phyllotaxy and staminal traces that join the vascular system of the reproductive-unit axis at different levels. The vasculature pattern of these units differs from the cyperoid flowers. On the basis of these results, it is inferred that the reproductive units of both species are inflorescences, composed of unisexual flowers. It is also inferred that this structure is the general pattern for Mapanioideae and that loss of male flowers and inner bracts has occurred during evolution of the subfamily.
\end{abstract}

Additional keywords: Hypolytreae, ontogeny, sedge inflorescence, unisexual flower, vasculature.

Received 11 December 2015, accepted 17 June 2016, published online 25 July 2016

\section{Introduction}

Cyperaceae is the third-largest family of the monocotyledons (Bruhl 1995; Goetghebeur 1998), comprising 106 genera and $\sim 5700$ species with a cosmopolitan distribution and centre of diversity in the Neotropics and Africa (Goetghebeur 1998; Govaerts et al. 2007). The family is distinguished by presenting compound, reduced inflorescences that are composed of several reproductive units subtended by bracts (Simpson 1992). The structure of the reproductive units is quite variable and such variation is a result of reduction processes and loss of structures during the evolution of the family (Dahlgren et al. 1985; Simpson 1992; Alves et al. 2001).

On the basis of morphological characteristics, Cyperaceae was divided into the following four subfamilies: Mapanioideae, Cyperoideae, Sclerioidae and Caricoideae (Goetghebeur 1998). However, later studies based on morphological and molecular data recognised only two subfamilies, namely Mapanioideae and Cyperoideae (Simpson et al. 2007; Muasya et al. 2009), which are easily distinguishable by the structure of their reproductive units. In Cyperoideae, the reproductive units are spikelets with at least one bisexual, trimerous, tetracyclic flower (Goetghebeur 1998; Simpson et al. 2007; Muasya et al. 2009). In Mapanioideae, the reproductive units are spicoids, each corresponding to several bracts, stamens and a single gynoecium (Eiten 1976; Simpson 1992; Bruhl 1995; Richards et al. 2006; Prychid and Bruhl 2013). Such reduced structure with unisexual flowers has already been interpreted as a single flower (Koyama 1971; Kern 1974; Goetghebeur 1998), raising debates about euanthial $\times$ synanthial hypotheses. Whereas in the euanthial hypothesis each reproductive unit is interpreted as a single flower, in the synanthial hypothesis, each unit is interpreted as an inflorescence composed of extremely reduced flowers, resembling a single flower (Bruhl 1991; Prychid and Bruhl 2013).

Both Mapania and Hypolytrum belong to Mapanioideae and differ from each other mainly by the inflorescence branching pattern and by the number of bracts in each reproductive unit (Eiten 1976; Dahlgren et al. 1985; Simpson 1992; Goetghebeur 1998). Mapania has capitate and globose inflorescences that are little branched because of the significant reduction of the main axis, with reproductive units with four to six bracts (Simpson 1992). In Hypolytrum, the inflorescences are paniculiform and intensely branched, with two or three bracts per reproductive unit (Simpson 1992; Alves et al. 2002; Alves 2003). Mapania pycnostachya is widely distributed in South America (Simpson 1992) and, in Brazil, it is restricted to the Amazon region (Alves 
et al. 2009). Hypolytrum schraderianum is the most common species of the genus, being widely distributed in the Neotropics (Alves 2003) and, in Brazil, it occurs in Amazon and Atlantic coastal forests (Alves et al. 2009).

The great majority of the studies about the reproductive units of Cyperaceae are related to Cyperoideae (e.g. Richards 2002; Vrijdaghs et al. 2004, 2005a, 2005b, 2009, 2010, 2011; Reutemann et al. 2012a). For Mapanioideae, developmental studies on their reproductive units have so far interpreted them as reduced inflorescences, comprising a variable number of male flowers and a single female or bisexual flower (Richards et al. 2006; Vrijdaghs et al. 2006; Prychid and Bruhl 2013). Vrijdaghs et al. (2006), for example, comparing the development of the reproductive units of Paramapania parvibractea (Mapanioideae) and Hellmuthia membranacea (Cyperoideae), observed in the first one that the lateral bracts are the first organs to emerge, followed by the stamens, inner bracts (when present) and gynoecium. This inflorescence development is different from that in the cyperoid species, in which the stamens are the first to emerge, followed by the gynoecium and the perianth (Vrijdaghs et al. 2006). Therefore, the authors concluded that, on the basis of the development, the bracts of the reproductive units of Paramapania parvibractea are not homologous to the perianth of the cyperoid flowers.

The same developmental pattern was observed in the reproductive units of Exocarya sclerioides (Mapanioideae) by Richards et al. (2006), as well as in Lepironia articulata (Mapanioideae) by Prychid and Bruhl (2013). These authors analysed not only the development of the reproductive units of $L$. articulata but also the immunolocalisation of the protein products of $A P 1-F U L$-like genes, localised only in floral structures, and their results supported the synanthial hypothesis as the evolutionary origin of the reproductive units in this species.

Considering the small number of studies concerning the reproductive units of Mapanioideae, it is important to understand the structure of these units in other members of the subfamily, especially those from the most species-rich genera (Mapania and Hypolytrum) that seem to present the most reduced units. Therefore, the present paper aimed to shed light on the understanding of the reproductive units of $M$. pycnostachya and $H$. schraderianum, the latter presenting reproductive units reduced to two lateral bracts, two stamens and a gynoecium, being very similar to a single flower. A comparative developmental and anatomical study was conducted, with emphasis on the vasculature pattern of the reproductive units, to answer the following question: do the stamens and gynoecium of each reproductive unit represent reduced individual flowers of an inflorescence or are they parts of a single flower?

\section{Materials and methods}

The samples of $M$. pycnostachya and $H$. schraderianum were collected from the Reserva Florestal Adolpho Ducke (Manaus, Amazonas, Brazil), in understorey humid areas of the Amazon rainforest. Voucher specimens are deposited at the Herbarium Rioclarense (HRCB) of the Universidade Estadual Paulista (Hypolytrum schraderianum - HRCB 62552; Mapania pycnostachya - HRCB 62551). Part of the collected material was fixed in 37\% formaldehyde-glacial acetic acid-50\% ethanol (1:1:18 v/v, FAA 50) (Johansen 1940) and the inflorescences were dissected in $50 \%$ ethanol under stereomicroscope for morphological and anatomical studies.

For analyses under light microscope, reproductive units were subjected to the n-butyl alcohol dehydration series, infiltration and inclusion in (2-hydroxyethyl)-methacrylate (Historesin Embedding Kit, Leica, Nussloch, Germany; Gerrits and Smid 1983). The embedded material was serially sectioned at $6-8 \mu \mathrm{m}$ on a rotation microtome (Leica RM 2245), stained in periodic acid-Schiff's reagent (PAS) and toluidine blue (O'Brien et al. 1964; Feder and O'Brien 1968) and mounted on permanent slides with Entellan (Merck, Darmstadt, Germany). Photomicrographs were obtained with a LAS (Leica Application Suite V 4.0.0) digital imaging system, using an image-capturing device (Leica DFC 450, Heerbrugg, Switzerland) coupled to a microscope (Leica DM4000B, Wetzlar, Germany).

For analyses under scanning electron microscope (SEM), reproductive units were dehydrated through an ethanol series, critical-point dried (Balzers CPD 030, Balzers, Liechtenstein), coated with gold (Bal-Tec SCD 050, Balzers) and examined in a Hitachi TM 3000 (Hitachi, Krefeld, Germany) SEM. The results were recorded using the TM 3000 Application Program (Hitachi, Krefeld, Germany).

So as to avoid conflicting terms to describe the same structures, the terminology adopted in the present paper follows the terms and definitions of Prychid and Bruhl (2013).

\section{Results}

Structure of the inflorescences and development of the reproductive units

The studied species have indeterminate synflorescences (Fig. 1a,e). The lateral branches originate from the axil of subtending leaves. Such subtending leaves are foliaceous and their size decreases from proximal to distal region of the main axis (Fig. 1a,e).

Mapania pycnostachya has synflorescences with lateral branches up to third order, and because the second-order lateral branches are short, the synflorescences are capitate (Fig. 1a). Each second-order axis has an adaxial prophyll and a bract (called the paracladium bract) that is located opposite the prophyll and axilates a third-order lateral axis (Fig. 1a). Each lateral axis (second and third orders) bears a spike (Fig. 1a) that corresponds to a raceme bearing many reproductive units, each being enveloped by a subtending bract (Fig. $1 b$ ). The reproductive unit is composed of two lateral bracts (prophyll-like units), zero to two stamens, two inner bracts (leaf-like structures) and one gynoecium (Fig. 1c). A diagrammatic representation of the reproductive unit is shown in the Fig. $1 d$.

Hypolytrum schraderianum has intensely branched synflorescences, with lateral axes up to fifth order (Fig. 1e). The lateral axes (second to fifth order) have an adaxial prophyll at their base and bear a spike (Fig. 1e) composed of many reproductive units, each being enveloped by a subtending bract (Fig. 1f). Each reproductive unit is composed of two prophyll-like units, two stamens and one gynoecium (Fig. $1 g$ ). The structure of the reproductive unit is diagrammatic represented in the Fig. $1 h$. 


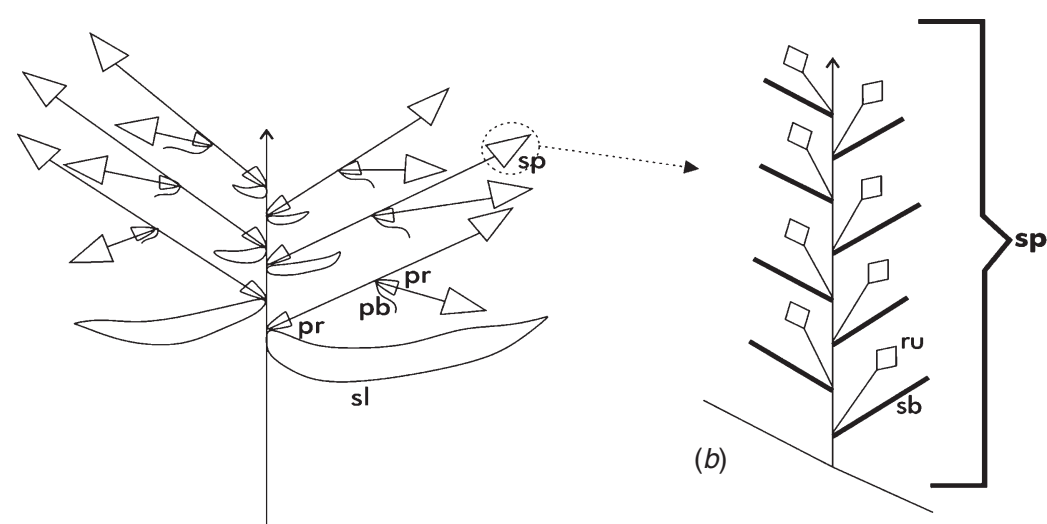

(a)

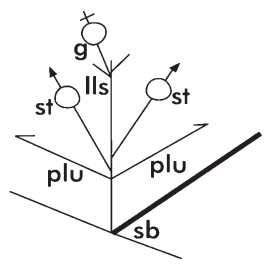

(c)

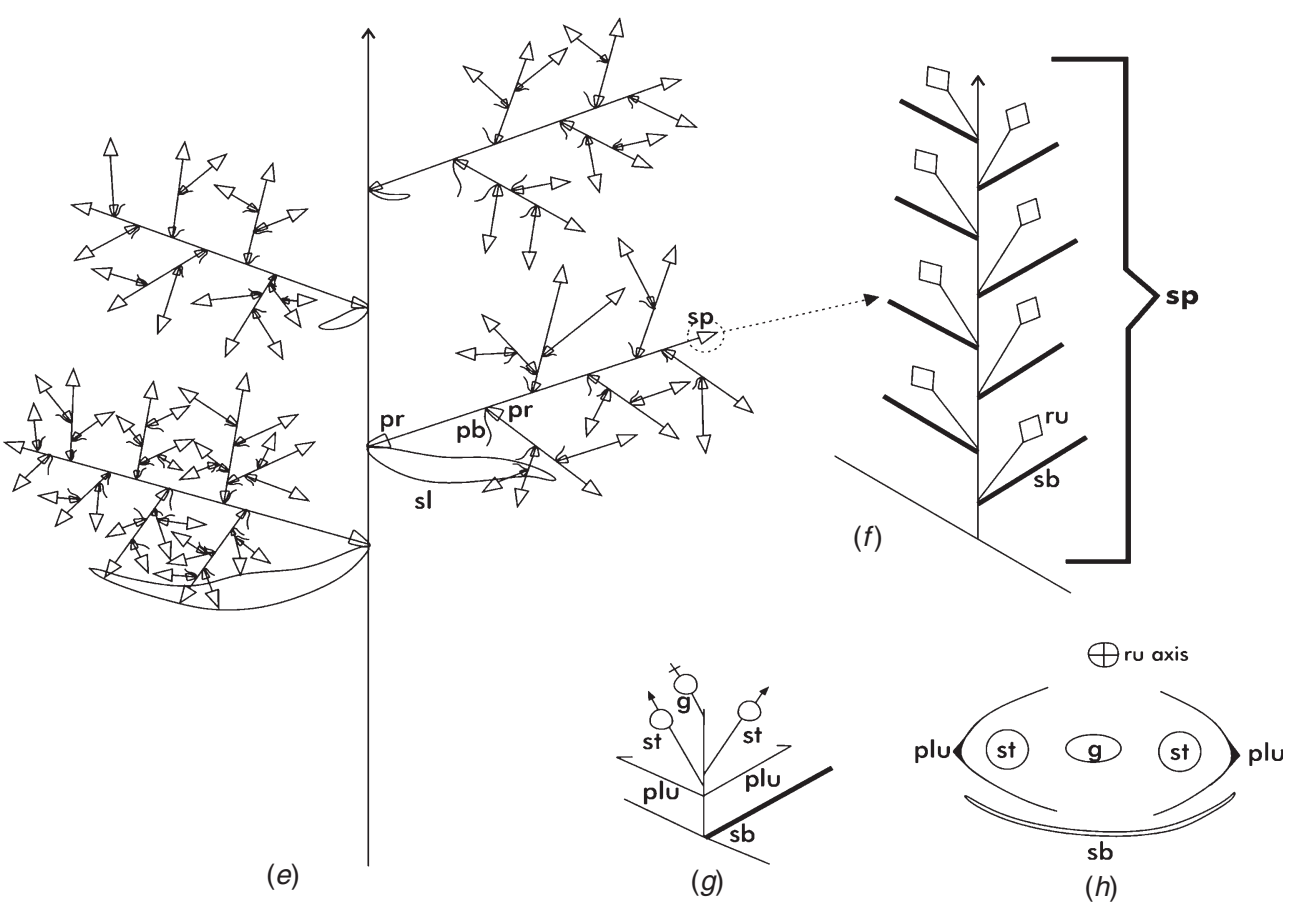

$\bigoplus$ ru axis

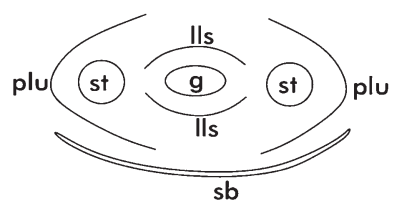

(d) (h)

Fig. 1. Schematic representation of the inflorescences of Mapania pycnostachya and Hypolytrum schraderianum. (a-c) M. pycnostachya. (a) Synflorescence. (b) Spike. (c) Axial scheme of a reproductive unit. (d) Diagrammatic representation of a reproductive unit. (e-h) H. schraderianum. (e) Synflorescence. ( $f)$ Spike. (g) Axial scheme of a reproductive unit. ( $h$ ) Diagrammatic representation of a reproductive unit. g, gynoecium; 1ls, leaf-like structures; pb, paracladium bract; plu, prophyll-like units; pr, prophyll; ru, reproductive unit; sb, subtending bract; sb, subtending leaf; sp, spike; and st, stamen.

In each spike the reproductive units arise acropetally in a spiral sequence and are enclosed by the subtending bracts (Figs $2 a, 3 a$, asterisks). The primordium of the reproductive unit is asymmetrical, being flattened adaxially and rounded abaxially (Figs 2b, 3b). During the development, two projections appear from the lateral ends, corresponding to the primordia of the two lateral bracts (prophyll-like units)
(Figs $2 c, d ; 3 c, d$ ). Such prophyll-like units are sub-opposite, adaxial, fused at the base and surround the stamens (Figs $2 d$; $3 e, f)$. The staminal primordia emerge subsequently, opposite to the prophyll-like units (Figs $2 c-e ; 3 d, e$ ). The stamens do not differentiate simultaneously (Figs $2 c-g ; 3 d, e$ ) and as the reproductive unit develops, it becomes clear the differences of heights between them (Figs $2 h, i ; 4 a, c, d$ ). Mapania 

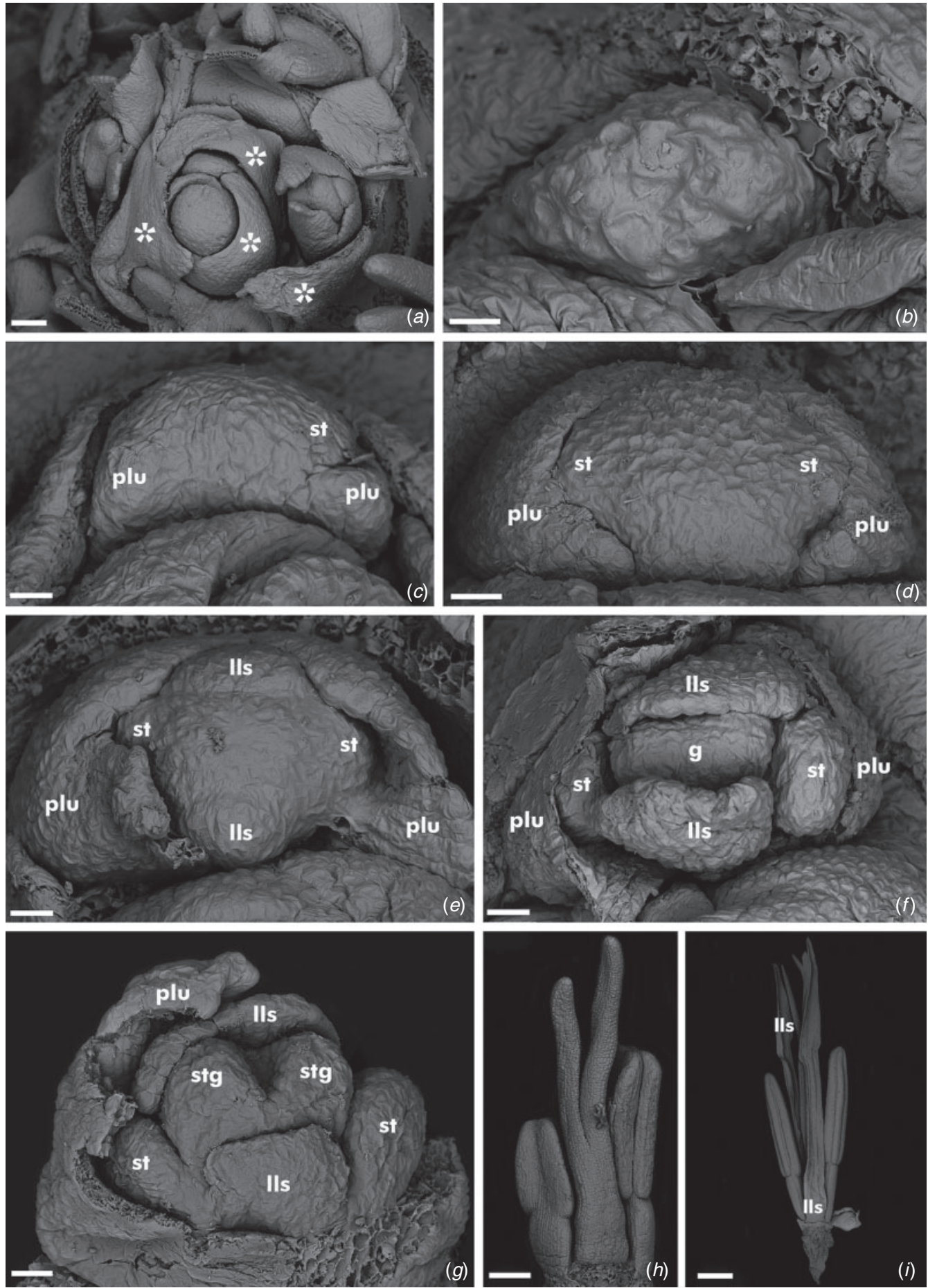

Fig. 2. Scanning electron micrographs of the reproductive units of Mapania pycnostachya at different developmental stages. (a) Spike axis with spirally initiated subtending bracts (asterisks) enveloping the reproductive units. (b) Reproductive-unit primordium, subtending bract removed. (c) Initiation of prophyll-like units and the first stamen. $(d)$ Development of prophyll-like units subtending the staminal primordia. (e) Initiation of inner leaf-like structures. $(f)$ Initiation of gynoecium. $(g$ ) Initiation of stigma primordia. $(h)$ Reproductive unit with prophyll-like units and leaf-like structures removed, showing the stamens and the gynoecium. (i) Mature reproductive unit with prophyll-like units removed, showing the stamens and the leaf-like structures surrounding the gynoecium. g; gynoecium; lls; leaf-like structures; plu, prophyll-like units; st, stamen; and stg, stigma. Scale bars $=41.4 \mu \mathrm{m}(a), 15 \mu \mathrm{m}(b-f), 25 \mu \mathrm{m}$ $(g), 83 \mu \mathrm{m}(h)$ and $0.4 \mathrm{~mm}(i)$. 

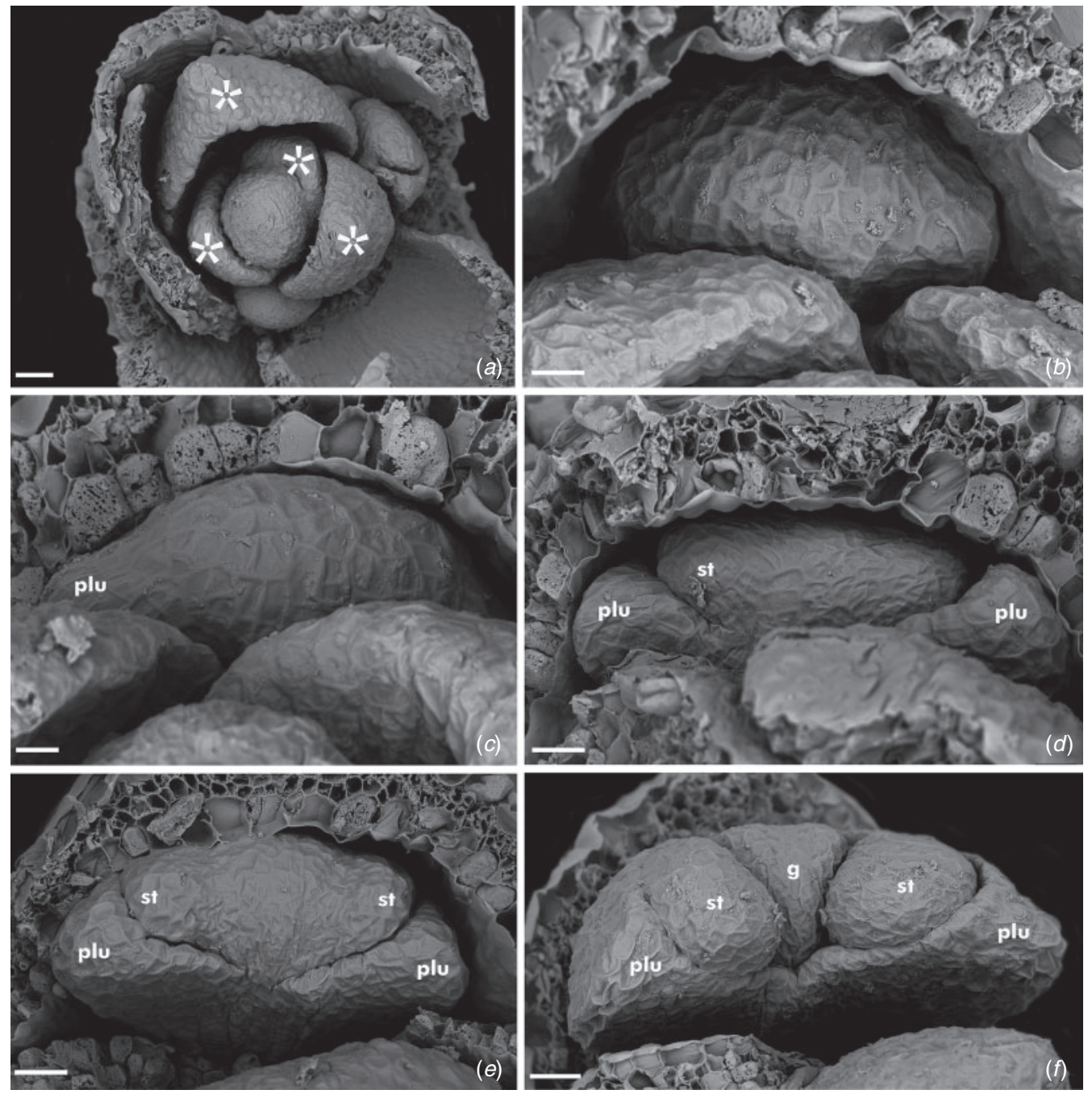

Fig. 3. Scanning electron micrographs of the reproductive units of Hypolytrum schraderianum at different developmental stages. (a) Spike axis with spirally initiated subtending bracts (asterisks) enveloping the reproductive units. (b) Reproductive-unit primordium, subtending bract removed. (c) Initiation of prophyll-like units. $(d)$ Development of prophyll-like units and initiation of the first stamen. $(e)$ Staminal primordia. $(f)$ Initiation of gynoecium. g, gynoecium; plu, prophyll-like units; and st, stamen. Scale bars $=25 \mu \mathrm{m}(a), 10 \mu \mathrm{m}(b, d, e), 5 \mu \mathrm{m}(c)$ and $15 \mu \mathrm{m}(f)$.

pycnostachya may have two, one or none stamens per reproductive unit and Hypolytrum schraderianum has always two stamens per reproductive unit.

In Mapania pycnostachya, after the stamens emerge, the primordia of two inner bracts (leaf-like structures) appear (Fig. 2e). These primordia are opposite to each other and surround the gynoecium (Fig. $2 f, g, i$ ). The latter emerges right after the initiation of the inner leaf-like structures (Fig. $2 f$ ) and occupies a distal position in the reproductive unit (Fig. $2 f, g$ ).

In Hypolytrum schraderianum, there are no inner leaflike structures and the primordial gynoecium emerges right after the stamen initiation (Fig. 3e,f). As was observed in $M$. pycnostachya, the gynoecium is formed by the congenital fusion of the carpels and occupies a distal position in the reproductive unit (Figs $3 f, 4 a-d$ ).

The primordial gynoecium of both species presents a slight depression in the middle and, on either side of this depression, two lateral projections appear, becoming the stigma primordia
(Figs $2 g, 4 b$ ). At this stage, the prophyll-like units are enveloping and protecting the stamens and gynoecium (Fig. 2g). The stigma primordia grow upward, becoming the stigmatic branches that are papillose at maturity (Figs $2 h, 4 d$ ).

\section{Vascularisation of the reproductive units}

In M. pycnostachya, the prophyll-like units and the inner leaflike structures are not vascularised and are similar morphological and anatomically (Fig. $5 b-d$ ). Apart from a few mesophyll cells in the basal region, they are composed only of epidermis (Fig. 5b-e). The prophyll-like units are fused from their median to basal region (Fig. $5 b-f$ ). The style is vascularised by two collateral bundles that correspond to the dorsal carpellary bundles (Fig. 5a). These bundles run throughout the ovary wall (Fig. $5 b, c$ ) and join the central vascular plexus at the base of the gynoecium (Fig. $5 d$ ), which is a result of the fusion of ventral carpellary bundles. The ovule 

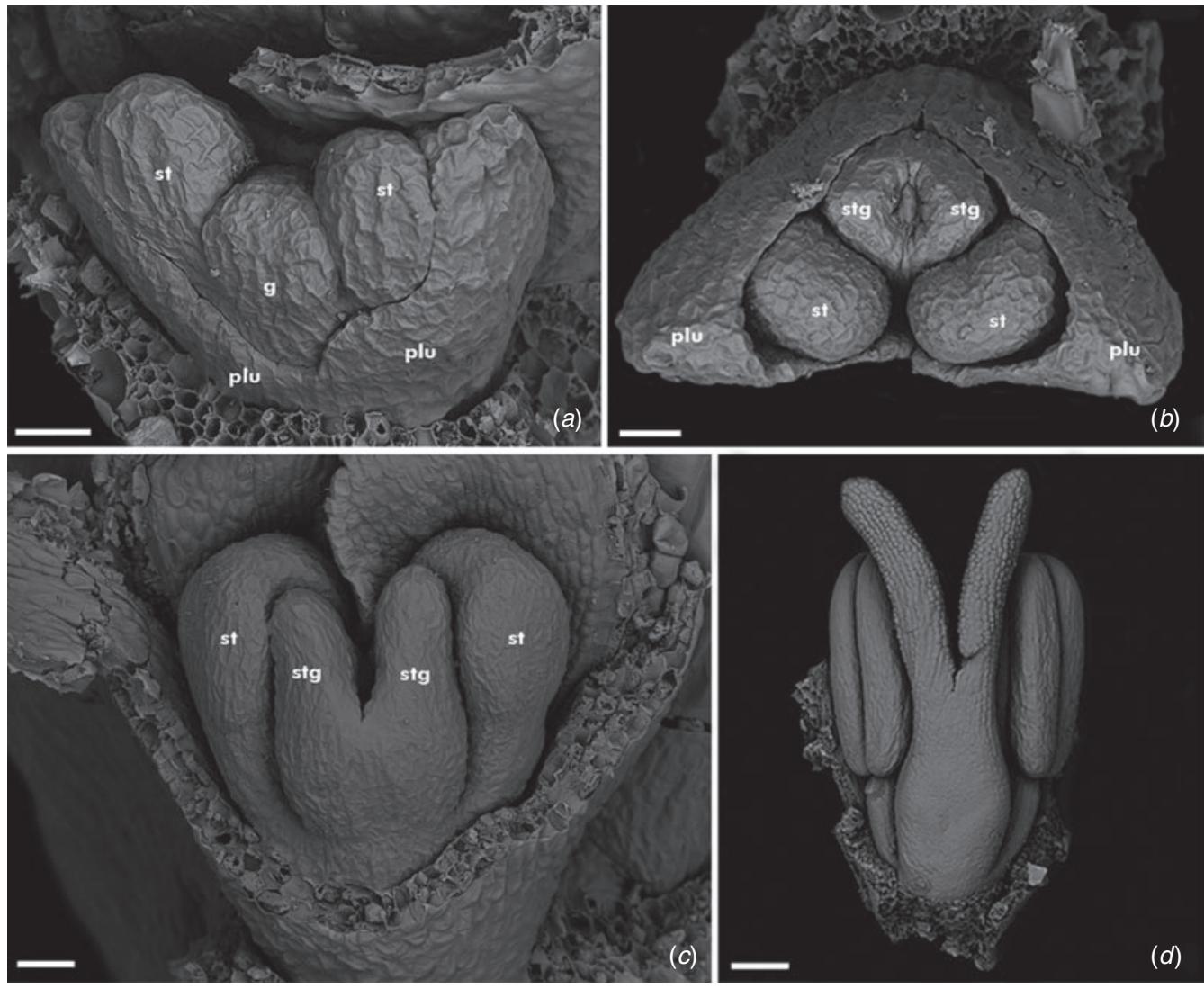

Fig. 4. Scanning electron micrographs of the reproductive units of Hypolytrum schraderianum at different developmental stages. (a) Divergence of the stamens at different levels and gynoecial primordium. (b) Stigma primordia, top view. (c) Development of stamens and stigma branches. (d) Mature reproductive unit with prophyll-like units removed, showing the two subopposite stamens diverging at different levels and the gynoecium. g; gynoecium; plu, prophyll-like units; st, stamen; and stg, stigma. Scale bars $=20 \mu \mathrm{m}(a-c)$ and $62.2 \mu \mathrm{m}(d)$.

vascular bundle also connects to the central vascular plexus (Fig. $5 c, d$ ). The anthers are tetrasporangiate, each one being vascularised by a single collateral vascular bundle that runs from the connective (Fig. 5a) to the filament (Fig. 5b-e) and that joins the vascular system of the reproductive-unit axis below the gynoecium (Fig. $5 g-j$ ). It can be observed that the vascular traces of stamens do not join the vascular system of the reproductive-unit axis at the same level (Fig. $5 g-i$ ). The vascular trace of one of the stamens connect first the vascular system of the reproductive-unit axis (Fig. $5 g-i$, arrowhead), followed by the connection of the vascular trace of the other stamen (Fig. $5 g-i$, arrow). The vascular tissues form a vascular plexus in the reproductive-unit axis of both species (Figs $5 e-j$, $6 e-i)$.

In $H$. schraderianum, each prophyll-like unit is vascularised by a single bundle, which lies under a distinctive keel (Fig. $6 a$ ). As was observed in $M$. pycnostachya, the prophyll-like units are fused from their median to basal region (Fig. $6 b-d$ ). The style is vascularised by two collateral bundles (Fig. $6 a$ ) that correspond to the dorsal carpellary bundles, which run throughout the ovary wall (Fig. $6 b, c$ ) and join the central vascular plexus at the base of the gynoecium (Fig. $6 c, d$ ). The ovule is supplied by the ovule vascular bundle (Fig. 6b) that connects to the central vascular plexus, which is a result of the fusion of the ventral carpellary bundles (Fig. $6 c, d$ ). The vascular traces of one of the stamens connect to the vascular plexus of the reproductive-unit axis (Fig. $6 e-g$, arrowhead) slightly ahead from the trace of the other stamen (Fig. 6e-g, arrow).

\section{Discussion}

On the basis of the results presented here, it is inferred that the reproductive units of both $M$. pycnostachya and H. schraderianum are inflorescences, corroborating prior evidence that the mapaniid reproductive unit is a synanthial structure (Eiten 1976; Simpson 1992; Richards et al. 2006; Vrijdaghs et al. 2006; Prychid and Bruhl 2013). Each reproductive unit of $M$. pycnostachya and $H$. schraderianum originates from the axil of a subtending bract and is constituted by two prophyll-like units, two male flowers and a female flower occupying a distal position, subtended or not by two leaf-like structures.

Several studies about the inflorescence patterns in angiosperms, at familial or suprafamilial levels, have demonstrated that the complexity of these structures is mainly related to the repetition of a basic branching pattern (Endress 2010; Stützel and Trovó 2013), as was observed in the studied species. In this point of view, it is possible to interpret the paracladium bract of the lateral branches as homologous to the subtending leaves of the main axis. The subtending leaves 

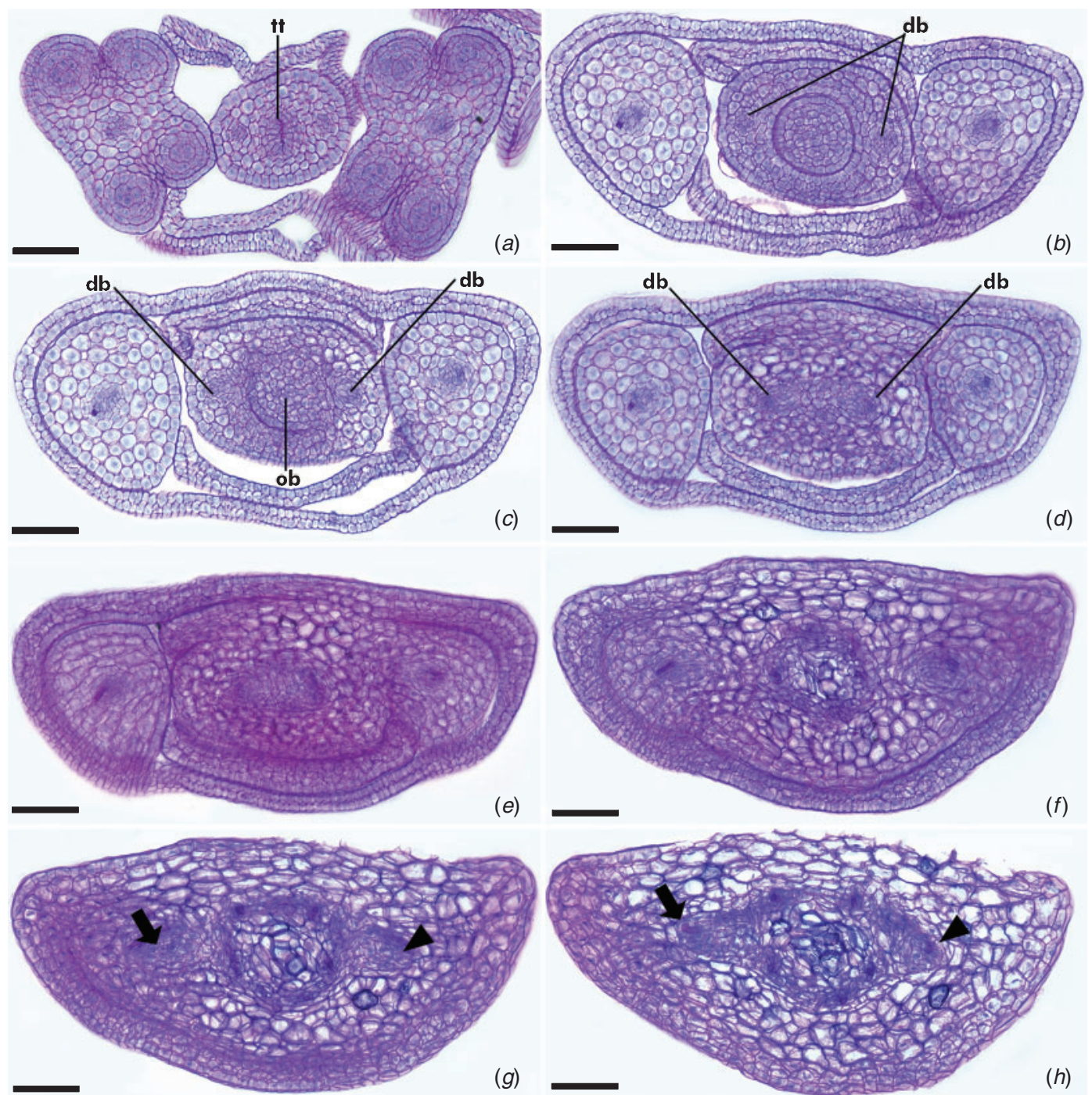

$(f)$
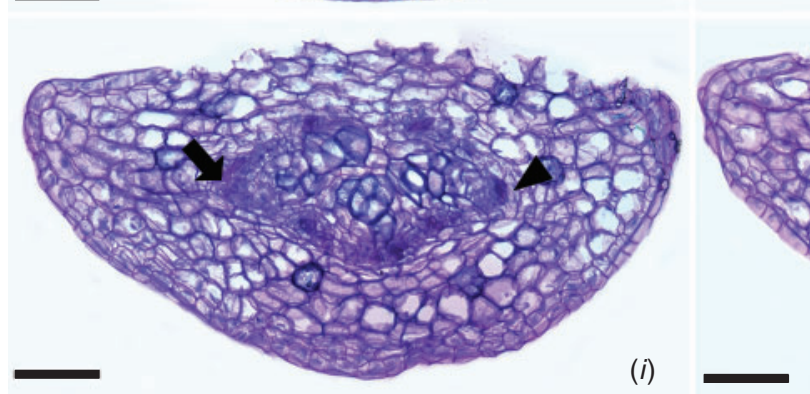

(h)

Fig. 5. Cross-sections of the reproductive unit of Mapania pycnostachya from apex to base, with subtending bract removed. (a) Upper region of reproductive unit, showing the anthers vascularised by a single vein, the inner leaf-like structures and the style with two veins. ( $b, c)$ Prophyll-like units composed only of epidermis, filaments, inner leaf-like structures, and the ovary vascularised by one ovule bundle and two dorsal carpellary bundles. $(d)$ Lower region of ovary, showing the central vascular plexus. (e) Connection of upper stamen to reproductive-unit axis. $(f)$ Connection of lower stamen to reproductiveunit axis. $(g-i)$ Vascular traces of stamens joining the vascular plexus of reproductive-unit axis; note that the vascular trace of one of the stamens connects to the vascular plexus of reproductive-unit axis slightly ahead (arrowhead) of the trace of the other stamen (arrow). ( $j$ ) Lower region of reproductive-unit axis. $\mathrm{db}$, dorsal carpellary bundle; ob, ovule vascular bundle; and tt, transmission tissue. Scale bars $=50 \mu \mathrm{m}(a)$ and $25 \mu \mathrm{m}(b-j)$.

protect the lateral meristems and determine the branching pattern of the inflorescence (Weberling 1989; Endress 1994, 2010). Opposite to the subtending leaves, an adaxial prophyll that surrounds the lateral branches can be observed. Considering that the reproductive units (spicoids) are the smaller unit of the inflorescence, and that they repeat the same basic branching 

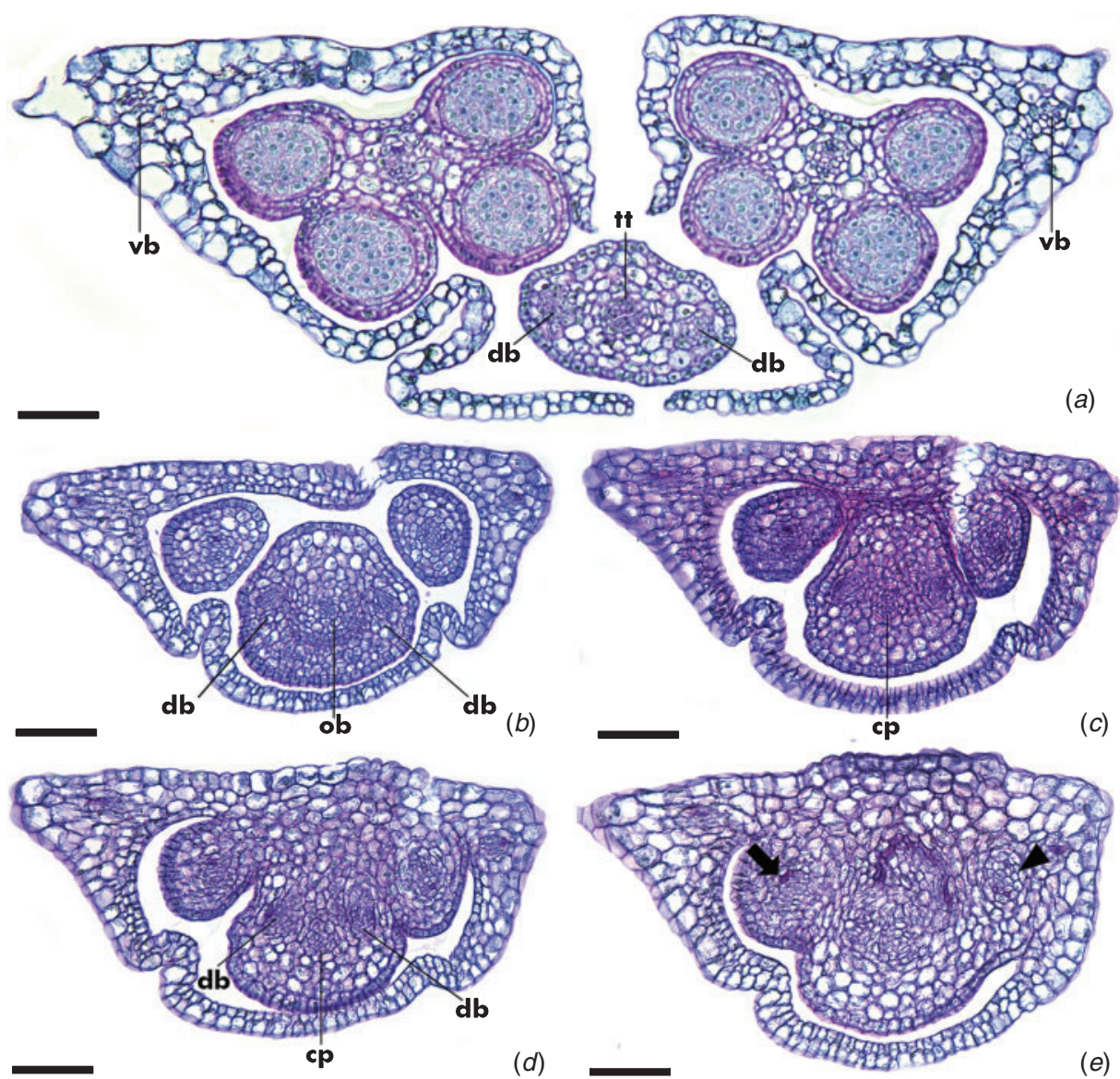

cp

(c)
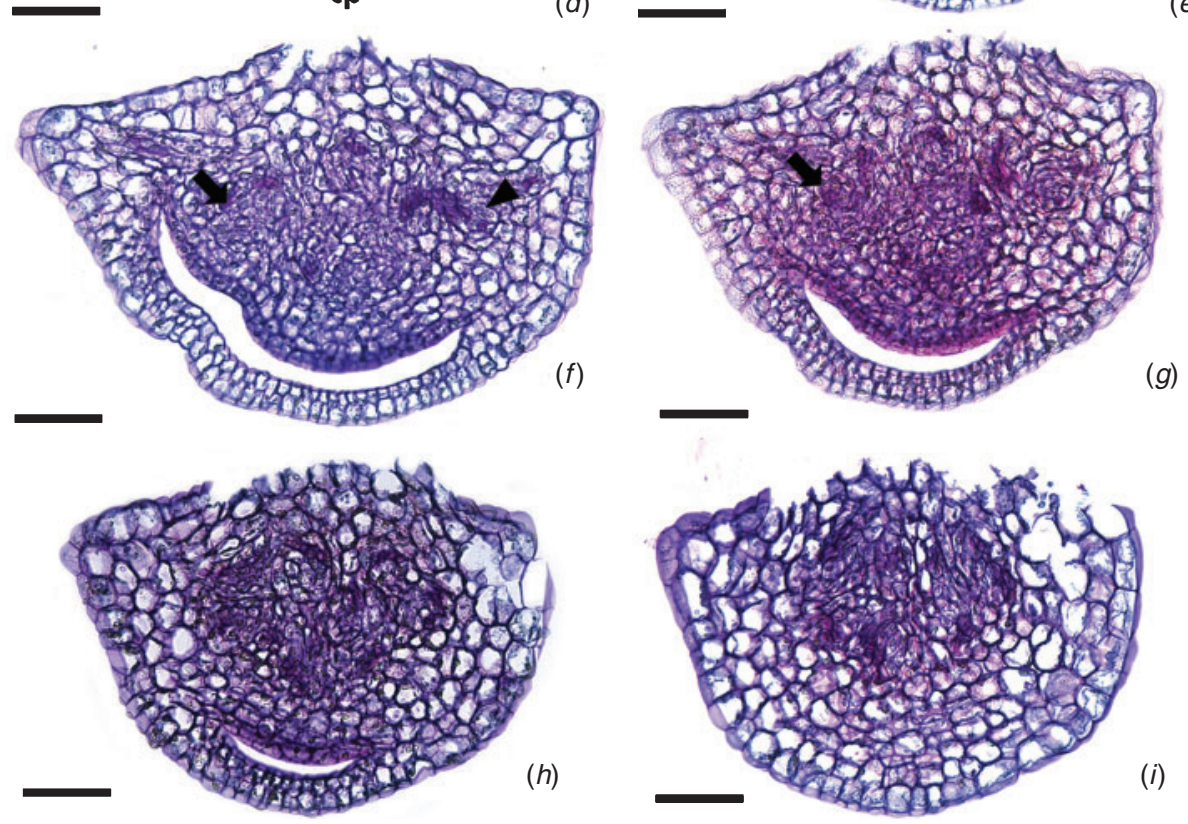

Fig. 6. Cross-sections of the reproductive unit of Hypolytrum schraderianum from apex to base, with subtending bract removed. (a) Upper region of reproductive unit, showing the keeled prophyll-like units and the anthers, each vascularised by a single vein, and the style with two veins. (b) Fused prophylllike units, filaments, and the ovary vascularised by one ovule bundle and two dorsal carpellary bundles. (c) Lower region of ovary, showing the central vascular plexus and connection of upper stamen to reproductive-unit axis. $(d)$ Connection of lower stamen to reproductive-unit axis. $(e-h)$ Vascular traces of stamens (arrowhead, arrow) and prophyll-like units joining the vascular plexus of reproductive-unit axis. (i) Lower region of reproductive-unit axis, showing the vascular plexus. cp, central vascular plexus; db, dorsal carpellary bundle; ob, ovule vascular bundle; tt: transmission tissue; and vb, vascular bundle of prophylllike unit. Scale bars $=50 \mu \mathrm{m}(a)$ and $25 \mu \mathrm{m}(b-i)$. 
pattern of the inflorescence, the lateral bracts (prophyll-like units) may also be interpreted as homologous to the prophyll.

In the monocotyledons, there is generally only one prophyll in each lateral inflorescence axis, in a proximal and adaxial position. For this reason, for other mapaniid species, the prophyll-like units were interpreted as a modified split prophyll (Holttum 1948; Richards et al. 2006; Prychid and Bruhl 2013). The prophyll-like units are usually present in the mapaniid reproductive units, and, in some species, they appear as a single open adaxial or abaxial bract, or even as a closed bract (Prychid and Bruhl 2013). In addition, the prophyll in Cyperaceae is generally two-keeled (Blaser 1944; Holttum 1948; Reutemann et al. 2012b), reinforcing the interpretation that the prophyll-like units, each one with a distinctive keel, are homologous to the two halves of a single prophyll. It is noteworthy that the prophyll-like units are well developed, because they assume the protection of the lateral male flowers that are achlamydeous.

According to Prychid and Bruhl (2013), the prophyll-like units are morphologically distinct from the inner leaf-like structures and do not show $A P 1-F U L$-like protein localisation (do not have a floral identity), which is present in the leaf-like structures. Therefore, the authors concluded that the prophylllike units are derived from extrafloral organs, whereas the leaf-like structures may be interpreted as perianth parts. In M. pycnostachya, both prophyll-like units and inner leaflike structures are not vascularised and are very similar morphologically and anatomically, being composed only of the adaxial and abaxial epidermis, with few mesophyll cells in their basal region. In H. schraderianum, the prophyll-like units are vascularised and have a distinctive keel, as is commonly found in the subfamily (Eiten 1976; Bruhl 1991; Richards et al. 2006; Prychid and Bruhl 2013). Thus, further immunohistochemical studies are necessary to confirm the nature of these structures in both species.

We emphasise that the terminology used to describe the structure of mapaniid reproductive units varies according to different authors. The subtending bract, which encloses the reproductive unit, receives the following designations: 'glumelike bract' (Eiten 1976; Vrijdaghs et al. 2006) or 'leaflike structure' (Richards et al. 2006). The prophyll-like units correspond to the 'lateral leaf-like structures' (Richards et al. 2006) or lateral scales (Vrijdaghs et al. 2006) and, despite the structural differences between the species studied here and those from the studies cited above, the differentiation of the two prophyll-like units at early stages of development occurs in all of these species and it seems like a pattern for the reproductive units of Mapanioideae. The inner leaf-like structures are designated as 'adaxial or abaxial leaflike structures' (Richards et al. 2006) or inner scales (Vrijdaghs et al. 2006) and are usually interspersed with the stamens or between stamens and gynoecium (Richards et al. 2006; Prychid and Bruhl 2013). Some authors do not differentiate between the prophyll-like units and the inner leaf-like structures, designating both as 'glumella' (Eiten 1976). Here, we follow the terminology used by Prychid and Bruhl (2013), based on the terms defined by Simpson (1992), who made a review of the terminology applied to mapaniid reproductive units.
The number of male flowers and leaf-like structures in each reproductive unit may vary among the mapaniid genera and, therefore, it has a taxonomic value (Holttum 1948; Eiten 1976; Bruhl 1991; Simpson 1992; Richards et al. 2006; Vrijdaghs et al. 2006; Prychid and Bruhl 2013). Considering the inflorescence morphology of the different mapaniid genera, it is believed that the structure of the reproductive unit (raceme-type inflorescence) is the general pattern for the subfamily and that male flowers and inner leaf-like structures have been lost during the evolution of the subfamily, along with the reduction of the size of reproductive-unit axis. Such evolutionary processes can be observed in Mapania, Hypolytrum and Chrysitrix (Simpson et al. 2003) and are evident when we compare the reproductive units of $M$. pycnostachya and $H$. schraderianum, the latter without inner leaf-like structures, but with the same floral organisation and vasculature pattern. It is also in accordance with the findings of previous authors, namely that reduction and loss of structures are the main trends of inflorescence evolution in Cyperaceae (Guarise and Vegetti 2008; Reutemann et al. 2012b).

Besides the presence of inner leaf-like structures, another evidence that the reproductive units of Mapanioideae are inflorescences is that the prophyll-like units initiate early during the development, arising before the stamens. Vrijdaghs et al. $(2005 a, 2005 b, 2006)$ observed that in the reproductive units (spikelets) of Cyperoideae, which have bisexual flowers, the development of perianth parts starts after the differentiation of the stamens. In contrast, in Paramapania (Vrijdaghs et al. 2006), Exocarya (Richards et al. 2006) and Lepironia (Prychid and Bruhl 2013), which belong to Mapanioideae, the prophylllike units develop before the stamens, as observed in M. pycnostachya and H. schraderianum. Such observations indicate that these structures are not homologous to the perianth parts of cyperoid flowers, corroborating the synanthial interpretation.

Furthermore, the stamens of the reproductive units of the studied species are subopposite and diverge at different levels, confirmed by the vasculature analysis, indicating a spiral phyllotaxy, as observed in the inflorescences of most of the angiosperms (Carpenter et al. 1995). Bradley et al. (1996) noted for Antirrhinum majus that the phyllotaxy of the apical meristem switches from decussate to spiral in the transition from vegetative to reproductive stage. However, when the meristem assumes a floral identity, it switches to a whorled phyllotaxy (Carpenter et al. 1995), as observed in the floral axes of monocots and other angiosperms (Endress 2006; Endress and Doyle 2007; Remizowa et al. 2010). In Cyperoideae, the stamens are the first floral organs in which the vascular bundles develop and their traces join the vascular system of the receptacle at the same level (Reynders et al. 2012). In contrast, in the reproductive units of $H$. schraderianum and M. pycnostachya, the prophyll-like units are the first organs to receive the vascular bundles, and the staminal traces join the vascular system of the reproductive-unit axis at different levels, indicating that the stamens are not at the same whorl. Such difference is subtle, mainly in H. schraderianum, probably because the reproductive-unit axis is extremely reduced and the flowers emerge from it in short time 
intervals, as was reported for Lepironia by Prychid and Bruhl (2013).

The organisation of the vascular system of the reproductiveunit axis is also different from that of the receptacle of cyperoid flowers (Blaser 1941a, 1941b; Reynders et al. 2012). In the axis of the reproductive units of both $M$. pycnostachya and $H$. schraderianum, the vascular tissues form a vascular plexus, with which the vascular traces of the male and female flowers connect, whereas in the receptacle of cyperoid flowers, the vascular tissues are organised as a ring of vascular bundles that supply the perianth, stamens and carpels, as observed in Rhynchospora consanguinea (Monteiro MM, Scatena VL, Oriani A, unpubl. data) and in other angiosperms (Puri 1951; Remizowa et al. 2013). The vascular system of the female flower in M. pycnostachya and $H$. schraderianum is similar to that observed in the gynoecium of cyperoid flowers (Blaser 1941a, 1941b; Reynders et al. 2012), in which the ventral carpellary bundles form a central vascular plexus that connects towards the ovule.

Several authors have considered the female flowers to be in a terminal position and interpret the mapaniid reproductive units as a determinate inflorescence (Simpson 1992; Richards et al. 2006; Prychid and Bruhl 2013). However, our interpretation is that these reproductive units are indeterminate racemes and that the apparent terminal position of the female flower is due to the displacement of its pedicel to an erect position, aligning it in the direction of the reproductive-unit axis, simulating the presence of a terminal flower, as noted by Eiten (1976) for other species of the family. This interpretation is supported by the presence of floral bracts subtending the female flower in M. pycnostachya and other mapaniid species, indicating its lateral origin. Sokoloff et al. (2006), in a study about flowerlike terminal structures in racemose inflorescences, pointed out that despite the presence of an open axis proving the absence of a terminal flower, sometimes an open axis is completely absent, even if all the flowers are lateral, what could explain the absence of an open axis in the studied species and their apparent terminal female flower. Furthermore, the maturation of the reproductive unit in the studied species is acropetal, as observed in indeterminate inflorescences (Weberling 1989; Sokoloff et al. 2006), corroborating our interpretation. In both species, the stamens initiate and mature before the gynoecium.

As a conclusion, the results of the present study, namely, the development of the prophyll-like units before the stamens, the divergence of the stamens at different levels, the spiral phyllotaxy of the reproductive unit, and the organisation of the vascular tissues in the reproductive-unit axis, allowed us to infer that the reproductive units of the studied species are inflorescences.

Considering that the angiosperms present a great diversity of their inflorescence structure (Endress 2006, 2010, 2011) and that the evolution of these structures is governed by both genetic mechanisms and the interaction with environment (Prusinkiewicz et al. 2007; Prenner et al. 2009), it is believed that the structural variations observed in the reproductive units of Mapanioideae are a result of the reduction and loss of male flowers and leaf-like structures during the evolution of the subfamily. This reduction has presumably increased the reproductive success of the species, especially in Mapania and Hypolytrum species, for which the transition from wind to insect pollination could have been a selective pressure (Lorougnon 1973; Goetghebeur 1998), as has also been reported for other monocots (Linder 1998; Rudall 2003; Sokoloff et al. 2009), including Cyperoideae species (Wragg and Johnson 2011; Lucero et al. 2014).

\section{Acknowledgements}

We thank the CNPq - Conselho Nacional de Desenvolvimento Científico e Tecnológico (MSc fellowship 130773/2013-1 to M.M.M.; Grant 168277/ 2014-0 to A.O.; Grant 301692/2010-6 to V.L.S.) and Fundação de Amparo à Pesquisa do Estado de São Paulo (Grant 2011/11536-3 to A.O.) for financial support. We also thank Dr Alessandra Ike Coan for providing the plant material.

\section{References}

Alves M (2003) Hypolytrum Rich. (Cyperaceae) nos Neotrópicos. PhD Thesis, Universidade de São Paulo, São Paulo, Brazil.

Alves M, Thomas WW, Wanderley MGL (2001) Typology of the inflorescence in species of Hypolytrum Rich. (Cyperaceae) from Brazil. Beitrage Biologie Pflanzen 72, 59-73.

Alves M, Estelita MEM, Wanderley MGL, Thomas WW (2002) Aplicações taxonômicas da anatomia foliar das espécies brasileiras de Hypolytrum Rich. (Cyperaceae). Revista Brasileira de Botanica. Brazilian Journal of Botany 25, 1-9. doi:10.1590/S0100-84042002000100002

Alves M, Araújo AC, Prata AP, Vitta F, Hefler S, Trevisan R, Gil ASB, Martins S, Thomas W (2009) Diversity of Cyperaceae in Brazil. Rodriguésia 60, 771-782.

Blaser HW (1941a) Studies in the morphology of the Cyperaceae I. Morphology of flowers. Scirpoid genera. American Journal of Botany 28, 542-551. doi:10.2307/2437000

Blaser HW (1941b) Studies in the morphology of the Cyperaceae I. Morphology of flowers. Rhynchosporoid genera. American Journal of Botany 28, 832-838. doi:10.2307/2436669

Blaser HW (1944) Morphology of the Cyperaceae. II. The prophyll. American Journal of Botany 31, 53-64. doi:10.2307/2437667

Bradley D, Vincent C, Carpenter R, Coen E (1996) Pathways for inflorescence and floral induction in Antirrhinum. Development 122, $1535-1544$

Bruhl JJ (1991) Comparative development of some taxonomically critical floral/inflorescence features in Cyperaceae. Australian Journal of Botany 39, 119-127. doi:10.1071/BT9910119

Bruhl JJ (1995) Sedge genera of the world: relationships and a new classification of the Cyperaceae. Australian Systematic Botany 8, 125-305. doi:10.1071/SB9950125

Carpenter R, Copsey L, Vincent C, Doyle S, Magrath R, Coen E (1995) Control of flower development and phyllotaxy by meristem identity genes in Antirrhinum. The Plant Cell 7, 2001-2011. doi:10.1105/tpc.7.12.2001

Dahlgren R, Clifford H, Yeo P (1985) 'The families of the monocotyledons: evolution and taxonomy.' (Springer-Verlag: Berlin)

Eiten LT (1976) Inflorescence units in the Cyperaceae. Annals of the Missouri Botanical Garden 63, 81-112. doi:10.2307/2395224

Endress PK (1994) 'Diversity and evolutionary biology of tropical flowers.' (Cambridge University Press: Cambridge, UK)

Endress PK (2006) Angiosperm floral evolution: morphological developmental framework. Advances in Botanical Research 44, 1-61. doi:10.1016/S0065-2296(06)44001-5

Endress PK (2010) Disentangling confusions in inflorescence morphology: patterns and diversity of reproductive shoot ramification in angiosperms. Journal of Systematics and Evolution 48, 225-239. doi:10.1111/j.1759-6831.2010.00087.x 
Endress PK (2011) Evolutionary diversification of the flowers in Angiosperms. American Journal of Botany 98, 370-396. doi:10.3732/ajb.1000299

Endress PK, Doyle JA (2007) Floral phyllotaxis in basal angiosperms: development and evolution. Current Opinion in Plant Biology 10, 52-57. doi:10.1016/j.pbi.2006.11.007

Feder N, O'Brien TP (1968) Plant microtechnique: some principles and new methods. American Journal of Botany 55(1), 123-142. doi: $10.2307 / 2440500$

Gerrits PO, Smid L (1983) A new, less toxic polymerization system for the embedding of soft tissues in glycol methacrylate and subsequent preparing of serial sections. Journal of Microscopy 132, 81-85. doi:10.1111/j.1365-2818.1983.tb04711.x

Goetghebeur P (1998) Cyperaceae. In 'The families and genera of vascular plants. Vol'.4.' (Ed. K Kubitzki) pp. 141-190. (Springer: Berlin)

Govaerts R, Simpson DA, Goetghebeur P, Wilson KL, Egorova T, Bruhl J (2007) 'World checklist of Cyperaceae. Sedges.' (Royal Botanic Gardens, Kew, Publishing: London)

Guarise NJ, Vegetti AC (2008) Processes responsible of the structural diversity of the Cyperaceae synflorescence: hypothetical evolutionary trends. Flora 203, 640-647. doi:10.1016/j.flora.2007.08.007

Holttum RE (1948) The spikelets in Cyperaceae. Botanical Review 14, 525-541. doi:10.1007/BF02861576

Johansen DA (1940) 'Plant microtechnique.' (McGraw-Hill Book Company: New York)

Kern JH (1974) Cyperaceae. In 'Flora Malesiana. Vol. 7'. (Ed. CGGJ van Steenis) pp. 435-753. (Noordhoff: Leyden, The Netherlands)

Koyama T (1971) Systematic interrelationships among Sclerieae, Lagenocarpeae and Mapanieae (Cyperaceae). Mitteilungen der Botanischen Staatssammlung München 10, 604-617.

Linder HP (1998) Morphology and the evolution of wind pollination. In 'Reproductive biology'. (Eds ST Owens, PJ Rudall) pp. 123-135. (Royal Botanic Gardens, Kew, Publishing: London)

Lorougnon G (1973) Le vecteur pollinique chez les Mapania et les Hypolytrum, Cypéracées do sous-bois des forêts tropicales ombrophiles. Bulletin du Jardin Botanique National de Belgique 43, 33-36. doi:10.2307/3667561

Lucero LE, Vegetti AC, Reinheimer R (2014) Evolution and development of the spikelet and flower of Rhynchospora (Cyperaceae). International Journal of Plant Sciences 175, 186-201. doi:10.1086/674317

Muasya AM, Simpson DA, Verboom GA, Goetghebeur P, Naczi RFC, Chase MW, Smets E (2009) Phylogeny of Cyperaceae based on DNA sequence data: current progress and future prospects. Botanical Review 75, 2-21. doi:10.1007/s12229-008-9019-3

O'Brien TP, Feder N, McCully ME (1964) Polychromatic staining of plant cell walls by toluidine blue O. Protoplasma 59, 368-373. doi:10.1007/BF01248568

Prenner G, Vergara-Silva F, Rudall PJ (2009) The key role of morphology in modelling inflorescence architecture. Trends in Plant Science 14, 302-309. doi:10.1016/j.tplants.2009.03.004

Prusinkiewicz P, Erasmus Y, Lane B, Harder LD, Coen E (2007) Evolution and development of inflorescence architectures. Science 316, 1452-1456. doi:10.1126/science.1140429

Prychid CJ, Bruhl JJ (2013) Floral ontogeny and gene protein location rules out euanthial interpretation of reproductive units in Lepironia (Cyperaceae, Mapanioideae, Chrysitricheae). Annals of Botany 112, 161-177. doi:10.1093/aob/mct111

Puri V (1951) The role of floral anatomy in the solution of morphological problems. Botanical Review 17, 471-553. doi:10.1007/BF02882536

Remizowa MV, Sokoloff DD, Rudall PJ (2010) Evolutionary history of the monocot flower. Annals of the Missouri Botanical Garden 97, 617-645. doi: $10.3417 / 2009142$
Remizowa MV, Rudall PJ, Choob VV, Sokoloff DD (2013) Racemose inflorescences of monocots: structural and morphogenetic interaction at the flower/inflorescence level. Annals of Botany 112, 1553-1566. doi:10.1093/aob/mcs246

Reutemann AG, Vegetti AC, Pozner R (2012a) Structure and development of the style base in Abildgaardia, Bulbostylis and Fimbristylis (Cyperaceae, Cyperoideae, Abildgaardieae). Flora 207, 223-236. doi:10.1016/j.flora.2012.01.008

Reutemann A, Lucero L, Guarise N, Vegetti AC (2012b) Structure of the Cyperaceae inflorescence. Botanical Review 78, 184-204. doi:10.1007/s12229-012-9098-z

Reynders M, Vrijdaghs A, Larridon I, Huygh W, Leroux O, Muasya AM, Goetghebeur P (2012) Gynoecial anatomy and development in Cyperoideae (Cyperaceae, Poales): congenital fusion of carpels facilitates evolutionary modifications in pistil structure. Plant Ecology and Evolution 145, 96-125. doi:10.5091/plecevo.2012.675

Richards JH (2002) Flower and spikelet morphology in sawgrass, Cladium jamaicense Crantz (Cyperaceae). Annals of Botany 90, 361-367. doi:10.1093/aob/mcf197

Richards JH, Bruhl JJ, Wilson KL (2006) Flower or spikelet? Understanding the morphology and development of reproductive structures in Exocarya (Cyperaceae, Mapanioideae, Chrysitricheae). American Journal of Botany 93, 1241-1250. doi:10.3732/ajb.93.9.1241

Rudall PJ (2003) Monocot pseudanthia revisited: floral structure of the mycoheterotrophic family Triuridaceae. International Journal of Plant Sciences 164, S307-S320. doi: $10.1086 / 376879$

Simpson D (1992) 'A revision of the genus Mapania.' (Royal Botanic Gardens, Kew, Publishing: London)

Simpson DA, Furness CA, Hodkinson TR, Muasya AM, Chase MW (2003) Phylogenetic relationships in Cyperaceae subfamily Mapanioideae inferred from pollen and plastid DNA sequence data. American Journal of Botany 90, 1071-1086. doi:10.3732/ajb.90.7.1071

Simpson DA, Muasya AM, Alves M, Bruhl JJ, Dhooge S, Chase MW, Furness CA, Ghamkhar K, Goetghebeur P, Hodkinson TR, Marchant AD, Nieuborg R, Reznicek AA, Roalson EH, Smets E, Starr JR, Thomas WW, Wilson KL, Zhang X (2007) Phylogeny of Cyperaceae based on DNA sequence data: a new $r b c \mathrm{~L}$ analysis. Aliso 23, 72-83. doi:10.5642/aliso.20072301.09

Sokoloff DD, Rudall P, Remizowa M (2006) Flower-like terminal structures in racemose inflorescences: a tool in morphogenetic and evolutionary research. Journal of Experimental Botany 57, 3517-3530. doi:10.1093/jxb/erl126

Sokoloff DD, Remizowa M, Linder HP, Rudall P (2009) Morphology and development of the gynoecium in Centrolepidaceae: the most remarkable range of variation in Poales. American Journal of Botany 96, 1925-1940. doi:10.3732/ajb.0900074

Stützel T, Trovó M (2013) Inflorescences in Eriocaulaceae: taxonomic relevance and practical implications. Annals of Botany 112, 1505-1522. doi:10.1093/aob/mct234

Vrijdaghs A, Goetghebeur P, Muasya AM, Smets E, Caris P (2004) The nature of the perianth in Fuirena (Cyperaceae). South African Journal of Botany 70, 587-594. doi:10.1016/S0254-6299(15)30196-4

Vrijdaghs AC, Caris P, Goetghebeur P, Smets E (2005a) Floral ontogeny in Scirpus, Eriophorum and Dulichium (Cyperaceae), with special reference to the perianth. Annals of Botany 95, 1199-1209. doi:10.1093/aob/mci132

Vrijdaghs A, Goetghebeur P, Muasya AM, Caris P, Smets E (2005b) Floral ontogeny in Ficinia and Isolepis (Cyperaceae), with focus on the nature and origin of the gynophore. Annals of Botany 96, 1247-1264. doi:10.1093/aob/mci276

Vrijdaghs A, Goetghebeur P, Smets E, Muasya AM (2006) The floral scales in Hellmunthia (Cyperaceae, Cyperoideae) and Paramapania (Cyperaceae, 
Mapanioideae): an ontogenetic study. Annals of Botany 98, 619-630. doi:10.1093/aob/mcl138

Vrijdaghs A, Muasya AM, Goetghebeur P, Caris P, Nagels A, Smets E (2009) A floral ontogenetic approach to homology questions within the Cyperoideae (Cyperaceae). Botanical Review 75, 30-51. doi:10.1007/s12229-008-9021-9

Vrijdaghs A, Reynders M, Larridon I, Muasya AM, Smets E, Goetghebeur P (2010) Spikelet structure and development in Cyperoideae, Cyperaceae: a monopodial general model based on ontogenetic evidence. Annals of Botany 105, 555-571. doi:10.1093/aob/mcq010
Vrijdaghs A, Reynders M, Muasya AM, Larridon I, Goetghebeur P, Smets E (2011) Spikelet and floral ontogeny in Cyperus and Pycreus (Cyperaceae). Plant Ecology and Evolution 144, 44-63. doi:10.5091/plecevo.2011.436

Weberling F (1989) 'Morphology of flowers and inflorescences.' (Cambridge University Press: Cambridge, UK)

Wragg PD, Johnson SD (2011) Transition from wind pollination to insect pollination in sedges: experimental evidence and functional traits. New Phytologist 191, 1128-1140. doi:10.1111/j.1469-8137.2011.03762.x 